\title{
ANTIHYPERGLYCAEMIC, ANTIHYPERLIPIDAEMIC AND ANTIHYPERTENSIVE EFFECT OF A POLYHERBAL FORMULATION IN ALLOXAN-INDUCED DIABETIC RATS
}

\author{
MALIK HASSAN MEHMOOD ${ }^{1,2 *}$, ABDUL MALIK ${ }^{2,3}$, MUHAMMAD SHOAIB AKHTAR $^{3}$, \\ GHULAM HAIDER $^{2}$, ANWARUL HASSAN GILANI ${ }^{2,4}$ \\ ${ }^{I}$ Department of Pharmacology, Faculty of Pharmaceutical Sciences, Government College University, Faisalabad-38000, Pakistan \\ ${ }^{2}$ Natural Product Research Division, Department of Biological and Biomedical Sciences, The "Aga Khan" University Medical \\ College, Karachi-74800, Sindh, Pakistan \\ ${ }^{3}$ College of Pharmacy, University of Sargodha, Sargodha, Pakistan \\ ${ }^{4}$ The University of Haripur, Haripur, Khyber Pakhtunkhwa, Pakistan
}

*corresponding author: malikhassan.mehmood@gmail.com

Manuscript received: October 2019

\begin{abstract}
Polyherbal formulation (POL-4) is popularly used by traditional practitioners to treat diabetes in district Badin, Sindh, Pakistan. This study validates the folk claim of POL-4 in diabetes and associated dysfunctions (hyperlipidaemia, endothelial dysfunction, hypertension) using OGTT and alloxan-challenged diabetic assays. Administration of POL-4 extract (300 mg/kg bw) markedly $(\mathrm{p}<0.01)$ lowered blood glucose levels compared to only glucose loaded $(2 \mathrm{~g} / \mathrm{kg}$ bw) rats. In alloxan (135 $\mathrm{mg} / \mathrm{kg} \mathrm{bw}$ ) fed rats, chronic (21 days) administration of POL-4 powder $(3 \%$ and $6 \% \mathrm{w} / \mathrm{w}$ in diet) significantly $(\mathrm{p}<0.001)$ prevented the rise in systolic blood pressure, heart rate, serum blood glucose and lipid parameters, while improved serum high density lipoprotein-cholesterol and endothelium-dependent aortic acetylcholine-mediated relaxation. POL-4 administration showed no signs of toxicity or lethality in mice at $1-5 \mathrm{~g} / \mathrm{kg}$ bw doses. These findings attest antihyperglycaemic, antihyperlipidaemic, endothelium modulatory and antihypertensive effects of POL-4, thus providing evidence to the folk use of POL-4 in diabetes and related complications.
\end{abstract}

\section{Rezumat}

În districtul Badin, Sindh, Pakistan, pentru tratamentul diabetului, este utilizată tradițional o formulare ce conține părți aeriene provenite de la mai multe plante (POL-4). Acest studiu validează folosirea POL-4 în diabet și disfuncții asociate (hiperlipidemie, disfuncție endotelială, hipertensiune), pe un model de diabet zaharat indus cu aloxan. Administrarea extractului POL-4 $(300 \mathrm{mg} / \mathrm{kgc})$ a scăzut semnificativ $(\mathrm{p}<0,01)$ nivelul glicemiei față de lotul control tratat cu glucoză $(2$ $\mathrm{g} / \mathrm{kgc})$. La șobolanii tratați cu aloxan $(135 \mathrm{mg} / \mathrm{kgc})$, administrarea cronică (21 zile) a POL-4 (3\% și $6 \% \mathrm{~m} / \mathrm{m}$ în dietă) a prevenit creșterea tensiunii arteriale sistolice, a ritmului cardiac, modificarea parametrilor serici glicemici și lipidici. POL-4 la dozele de $1-5 \mathrm{~g} / \mathrm{kgc}$ nu a prezentat semne de toxicitate la şoareci.

Keywords: alloxan-induced diabetes, POL-4, antihyperglycaemic, antihyperlipidaemic, antihypertensive

\section{Introduction}

Diabetes is an alarming health burden of the modern society, commonly prevailing as diabetes type 2 (more than 90\%) [1]. Persistent hyperglycaemia in diabetes may damage and cause failure of diverse body organs like eyes, kidneys, peripheral neurons, blood vessels (micro and macro) and heart [2]. Diabetes has become pandemic affecting 387 million individuals globally, its predicted prevalence from $8.3 \%$ in 2014 will increase to $10 \%$ by the year 2030 [3]. Diabetes dependent mortality is reported around $80 \%$ or even more in developing countries. Pakistan is ranked at $7^{\text {th }}$ position in the world with 6.9 million diabetic patients and expected to be at $4^{\text {th }}$ position in 2025 with estimated 11.5 million diabetic patients [4]. Hyperlipidaemia is a known and a common co-morbid in diabetic patients
[5]. Around $70 \%$ to $97 \%$ cases develop endothelial dysfunction and hypertension in diabetic patients with hyperlipidaemia.

A diverse range of pharmacological agents are available for the treatment of diabetes such as oral (biguanides, sulphonylureas and alpha-glucosidase inhibitors) or injectable (insulin and its analogues) preparations, however, their use is associated with wide range of adverse effects including development of increased risk of hypoglycaemia, lactic acidosis, weight gain, gastrointestinal toxicities, liver injury, heart and kidney failures [6]. Hence, the global interest is turning towards search of newer drugs that could combat diabetes progression in an innovative, effective and safe manner. Among alternative measures to address diabetes, medicinal plants/herbs are playing an important role in the management of metabolic diseases and related 
cardiovascular issues. It has been predicted that more than $25 \%$ of the prescription drugs in developed countries are derived from plants/herbs. World Health Organization has estimated that herbal remedies are being used in three quarters of the world population for their primary health care need [7]. Thus, medicinal herbs are preferred for the management of diabetes either as single herb [8] and/or polyherbal formulations (Diasulin and Cogent $\mathrm{db}$ ) [9, 10]. Polyherbal formulation (POL-4) is comprised of Nigella sativa, Gymnema sylvestr, Trigonella foenum graecum and Cichorium intybus. It is used by traditional practitioners for the treatment of cardiovascular disorders and diabetes in interior parts of Sindh province, Pakistan [11, 12]. Description of the ingredients of POL-4, including their common names, parts used, family, traditional uses and phytochemical composition, is presented in Table I. There are a few reports available supporting the effectiveness of the ingredients ( $G$. sylvestre, $T$. foenum graecum, N. sativa) of POL-4 in diabetes [1316], however, little is known about the usefulness of $C$. intybus, while no reports are available for the effectiveness of polyherbal formulation (POL-4) effectiveness in diabetes. POL-4 has also been studied for its cardiovascular and antihyperlipidaemic effects $[11,12]$. The current study validates the folk claim of traditional practitioners for the effectiveness of POL-4 in diabetes using OGTT assay and alloxaninduced diabetic rats.

Table I

Description of the components of polyherbal formulation (POL-4)

\begin{tabular}{|c|c|c|c|c|c|}
\hline $\begin{array}{c}\text { Components of } \\
\text { POL-4 (herbs) }\end{array}$ & $\begin{array}{c}\text { Common } \\
\text { names }\end{array}$ & $\begin{array}{c}\text { Parts } \\
\text { used }\end{array}$ & Family name & Traditional uses & Phytochemical composition \\
\hline Nigella sativa, L. & $\begin{array}{c}\text { Kalonji/Black } \\
\text { cumin }\end{array}$ & Seeds & Ranunculaceae & $\begin{array}{c}\text { antidiabetic, antihyper-lipidaemic, } \\
\text { diuretic, cardio- protective }\end{array}$ & $\begin{array}{c}\text { Thymoquinone, volatile oil, } \\
\text { saponins, flavonoids [13] }\end{array}$ \\
\hline $\begin{array}{c}\text { Cichorium } \\
\text { intybus, L. }\end{array}$ & Kasni/ chicory & Seeds & Asteraceae & $\begin{array}{c}\text { Cardiotonic, antidiabetic, } \\
\text { cholesterol lowering effect }\end{array}$ & $\begin{array}{c}\text { Caffeoylquininc acid, } \\
\text { chlorogenic acid, flavonoids, } \\
\text { phenolics, tannins [14] }\end{array}$ \\
\hline $\begin{array}{c}\text { Trigonella foenum } \\
\text { graecum, L. }\end{array}$ & $\begin{array}{c}\text { Methi-dana/ } \\
\text { Fenugreek }\end{array}$ & Seeds & Fabaceae & $\begin{array}{c}\text { Lipid lowering, cardio- } \\
\text { protective, hypoglycaemic }\end{array}$ & $\begin{array}{c}\text { Trigonelline, 4-hydroxyisoleucine, } \\
\text { diosgenin, flavonoids [15] }\end{array}$ \\
\hline $\begin{array}{c}\text { Gymnema } \\
\text { sylvestre, R.Br. }\end{array}$ & $\begin{array}{c}\text { Gurmar-booti//Leaves } \\
\text { Ram's horn/ } \\
\text { Periploca of } \\
\text { the wood }\end{array}$ & Asclepiadaceae & $\begin{array}{c}\text { Antidiabetic, lipid lowering, } \\
\text { cardio-effective, anti-obesity }\end{array}$ & $\begin{array}{c}\text { Gymnemic acid, } \\
\text { deacylgemnemic acid, saponins, } \\
\text { gurmarin, flavonoids, phenolics } \\
\text { [16] }\end{array}$ \\
\hline
\end{tabular}

\section{Materials and Methods}

Drugs, chemicals and kits used

Acetylcholine chloride, alloxan monohydrate, phenylephrine hydrochloride and glibenclamide were procured from Sigma (St. Louis, MO, USA). The kits for blood glucose, total cholesterol, triglycerides, low density lipoprotein-cholesterol and high density lipoproteincholesterol estimation were acquired from Roche Diagnostics and used Cobas c 111 for analysis. Anaesthetic agent (isoflurane) was received from Times Medicose Pharmacy outlet, Karachi, Pakistan. The various salts were mixed to prepare physiological solution which includes potassium chloride; potassium dihydrogen phosphate, sodium chloride, magnesium chloride, magnesium sulphate, sodium dihydrogen phosphate, calcium chloride, glucose and sodium bicarbonate were obtained from E. Merck, Darmstadt, Germany. Chemicals and reagents obtained for histological investigations containing formalin, buffer solution, ethanol, xylene, liquid paraffin, haematoxylin, eosin and DPX for mounting slides were available at "Aga Khan" University, Karachi, Pakistan. All the chemicals were of purity grade.

Collection and identification of plants

Plants were purchased from herbal enterprise, Rehmania Pinsar Shop, Sargodha, Pakistan and validated by Taxonomist, Dr. Amin Shah, University of Sargodha,
Sargodha, Pakistan. The samples of ingredients of POL-4 were preserved in the herbarium under the following voucher numbers: Malik-632 (N. sativa), Malik-633 (C. intybus), Malik-634 (T. foenum graecum) and Malik-635 (G. sylvestre). The individual plant material was weighed, taken in equal part and combined ingredients of POL-4 were pulverized with herbal grinder and mixed thoroughly to get the compound herbal formulation, POL-4. The powdered materials were stored at $4{ }^{\circ} \mathrm{C}$ in air tight jars.

Preparation of the extract of polyherbal formulation (POL-4)

For the preparation of the aqueous-methanolic extract of POL-4, $500 \mathrm{~g}$ powdered material of POL-4 was soaked in defined proportion of aqueous-methanol (30:70) mixture for three days with occasional shaking. The initial filtrate obtained was subjected for filtration process applying a muslin cloth and passed through Whatman filter No.1. The method was repeated thrice and the resultant filtrates were mixed together and evaporated using rotary evaporator [17]. The obtained semi solid extract of POL-4 (POL-4.Cr) was air dried with resultant yield of $16 \% \mathrm{w} / \mathrm{w}$.

Phytochemical analysis

Qualitative phytochemical screening was carried out to determine alkaloids, anthraquinones, flavonoids, tannins, saponins, coumarins and terpenoids as constituents of POL-4 [18]. 


\section{Laboratory animals}

Sprague Dawley (SD) rats with weight ranges of 180 $200 \mathrm{~g}$ and BALB/c mice $(20-25 \mathrm{~g})$ of both sexes were used in this study. Animals were sourced from Dow University of Health Sciences, Karachi and were bred at the animal house of "Aga Khan" University, Karachi, Pakistan. Animals were managed at $23 \pm$ $2{ }^{\circ} \mathrm{C}$ and $55 \pm 5 \%$ relative humidity with twelve-hrs day/night cycles. There were kept in plastic cages containing sawdust which was replaced after every two days. Standard diet and drinkable water was given to all animals. The animals were acclimatized for 5 - 7 days prior to experimentation. The study scheme was approved (57-ECACUBBS-15) by Ethics Committee for Animal Care and Use (ECACU) of the “Aga Khan" University, Karachi, Pakistan, and was also in line with the rules of Institute of Laboratory Animal Resources, NRC (National Research Council) [19].

Experimental design

Effect of POL-4 intervention on oral glucose tolerance test (OGTT) in rats

SD rats were fasted for 12 - 14 hours and were divided randomly into five groups with $5-7$ animals in each group for the OGTT assay. Group 1 served as normal control and received drinking water orally $(10 \mathrm{~mL} / \mathrm{kg} \mathrm{bw})$. Animals of group 2 were administered $2 \mathrm{~g} / \mathrm{kg}$ bw of glucose load and served as OGTT control. Group 3 was administered glibenclamide (6 $\mathrm{mg} / \mathrm{kg}$ bw, orally) dissolved in distilled water along with glucose load ( $2 \mathrm{~g} / \mathrm{kg}$ bw). Group 4 and 5 were also administered hydro-alcoholic extract of polyherbal formulation (POL-4) at 150 and $300 \mathrm{mg} / \mathrm{kg}$ bw along with glucose load. After $30 \mathrm{~min}$ of oral glucose load ( $2 \mathrm{~g} / \mathrm{kg} \mathrm{bw})$, blood samples were withdrawn from tail veins of rats at $0,30,60,90$ and 120 min intervals to estimate the blood glucose levels using Roche ACCU-Check glucometers.

Effects of POL-4 intervention on alloxan-induced diabetic rats

Freshly prepared alloxan monohydrate $(135 \mathrm{mg} / \mathrm{kg}$ bw) was injected intraperitoneally once to SD rats on fasting (12 - $16 \mathrm{hrs})$, it is immediately transported to pancreas through glucose transporter 2, due to similarity with glucose, which imparts deleterious effects on the $\beta$-cells of the pancreas [20]. The animals were given free access to food and tap water during the experiment. Blood glucose was measured using ACCU Check glucometer and rats having glucose levels of $>250 \mathrm{mg} / \mathrm{dL}$ were chosen in this study. The animals of group $1(n=6)$ were administered normal saline only, while animals in group $2-5(n=6-7$ in each group) were administered the above mentioned amount of alloxan monohydrate at a single dose. The group 2 was kept as negative control, while group 3 was administered glibenclamide $(6 \mathrm{mg} / \mathrm{kg}$ bw/day, orally), the standard oral hypoglycaemic agent. After fourth day of induction of diabetes in alloxanized animals, the animals of group 4 and 5 were treated with POL-4 (3\% and 6\%) powder mixed in the diet for 21 days. Physiological parameters (food and water intake), biochemical parameters (glucose and lipids) were measured by using Cobas c-111 analyser at terminal day of the study.

Measurement of endothelial reactivity in isolated rat aortae

At the end of study, SD rats were kept fasted for 12 - 14 hrs, $2-5 \% \mathrm{v} / \mathrm{w}$ isoflurane was used as inhalational anaesthesia to achieve deep sedation and finally euthanization of these animals. Afterwards, dissection was quickly performed to remove carefully thoracic aorta. The descending thoracic aortic tube was isolated and kept in Kreb's solution for vascular tension assay to study the endothelial function. The aortic rings were fixed in a tissue bath assembly filled with Kreb's solution $\left(37^{\circ} \mathrm{C}\right)$ and carbogen $\left(\mathrm{O}_{2}=95 \%\right.$ and $\mathrm{CO}_{2}=$ $5 \%)$ bubbles. Force transducer (50-7905, Harvard Apparatus, USA) linked to a Trans-bridge (Model No. TBM4M, World Precision Instruments, UK) and PowerLab setup (ADInstruments, Australia) was used for the assessment of tissue responses. The aortic rings were stabilized to equilibrate at $1-2 \mathrm{~g}$ of resting tension for 45 min with change of buffer at every 15 min intervals. When rings got stabilized, acetylcholine (Ach; $1 \times 10^{-8}-10^{-4} \mathrm{~mol} / \mathrm{L}$ ) inhibitory response curves were constructed against the induced contractions of phenylephrine (P.E) concentration of $1 \times 10^{-6} \mathrm{~mol} / \mathrm{L}$ [21].

Determination of blood pressure using non-invasive method

Non-invasive blood pressure (BP) was measured at day 0 and at $2^{\text {nd }}$ week of the study using plethysmography (Model No. 92, IITC Inc. USA) with tail cuff coupled with PowerLab data acquisition system attached to a computer with Lab Chart software (version 5.3) installed. Before starting the study protocol, SD rats were trained in the restrainers for the smooth BP measurements. When the animals became acclimatized to the training procedures, 3 - 5 readings of SBP (systolic blood pressure) within a time interval of $3-6 \mathrm{~min}$ were recorded in awaked rats and the readings were calculated according to mean values. Possible experimental variables such as body temperature $\left(27^{\circ} \mathrm{C}\right)$ of the animals, respiration rate, body motions and intensity of noise were minimized [22].

Collection of blood samples

For terminal blood collection, the animals were starved for 12 - $16 \mathrm{hrs}$ and anesthetized with inhalational isoflurane $(2-5 \% \mathrm{v} / \mathrm{w})$ in chambers until achievement of anaesthesia. By cardiac puncture procedure, blood was withdrawn from these animals in pre-labelled vacutainers. However, occasional blood samples for baseline levels were collected by puncturing tail vein of the rats. The serum was separated after centrifugation using Beckman centrifuge X-22 at 3000 revolution/min for $10 \mathrm{~min}$. The pancreatic and aortic tissues were 
isolated and from each animal and were preserved for histomorphological examination and endothelial reactivity studies, respectively.

\section{Estimation of biochemical parameters}

The serum total cholesterol, low density lipoproteincholesterol, high density lipoprotein cholesterol, triglyceride and glucose were estimated by means of Cobas c-111 auto-analyser diagnostic system (Roche Diagnostics Switzerland).

Histomorphological studies of isolated tissue specimens At last day of alloxan-induced diabetic experiment, the animals were anaesthetized with inhalation route by using isoflurane solution of $2-5 \% \mathrm{v} / \mathrm{w}$ in a closed jar and were perfused with intra-cardiac infusion (cannulation with aorta of heart) of saline to wash the blood from whole body including pancreas. The tissue specimens from the pancreas and the aortae of the control and the treated animals were harvested. Further, pancreatic tissues were preserved and perfused with neutral formalin (10\%) and later embedded in paraffin for $24-48 \mathrm{hrs}$. The paraffin blocks were cut off into $5 \mu \mathrm{m}$ sections and procedure of haematoxylin/ eosin (H/E) staining were carried out for microscopic examination using light microscope. For studying pancreatic architecture, system microscope (Olympus DX 43, Tokyo, Japan) and photographic digital camera were used for estimation of islet numbers while for the measurement of islet diameter, calibrated micrometre was used [23]. The observed histomorphological changes of pancreatic tissues of untreated and treated animals were noted by comparing with the corresponding tissue slides of the disease control animals.

Acute toxicity testing in mice

For acute toxicity, BALB/c mice (20 - $25 \mathrm{~g}$ ) of both sexes were selected and were distributed randomly in different groups of ten mice/group. The increasing doses (1, 3 and $5 \mathrm{~g} / \mathrm{kg}$ bw) of POL-4 extract were administered to overnight fasted mice. The animals of the control group were administered normal saline (orally, $10 \mathrm{~mL} / \mathrm{kg}$ ). All mice had free access to water and food and were kept under observation for any toxic effects like gastrointestinal spasm, anorexia, diarrhoea and/or mortality for $48 \mathrm{hrs}$. After $48 \mathrm{hrs}$, the survived animals were euthanized for organ necropsy to check whether the extract of POL-4 caused any damage to the vital organs including heart, liver, kidneys, pancreas and intestines as described by [24]. Statistical analysis

Data is displayed as mean \pm S.E.M. For comparison of two groups, unpaired Student's t-test was applied, while for comparison of multiple groups with control, One-way ANOVA (analysis of variance) was used tailed by Tukey's post-test and/or Dunnett's test. The P-value $(\mathrm{p}<0.05)$ was considered significant statistically. All graphs were constructed and statistical analysis was carried out using GraphPad Prism software (version 4.00).

\section{Results and Discussion}

\section{Phytochemical analysis}

The qualitative phytochemical analysis of the aqueousmethanolic extract of POL-4 showed saponins, alkaloids, anthraquinones, flavonoids, tannins, coumarins and terpenoids as POL-4 constituents.

Effect of POL-4 on oral glucose tolerance test in rats The oral glucose tolerance test (OGTT) was carried out to assess the hypoglycaemic activity of the aqueousmethanolic extract of polyherbal formulation (POL4.Cr). The solution of glucose $(2 \mathrm{~g} / \mathrm{kg} \mathrm{bw})$ was given to the normal rats. Glucose intake significantly ( $\mathrm{p}<$ 0.001 ) increased blood glucose levels in the animals at $30 \mathrm{~min}$ to $120 \mathrm{~min}$ after the glucose load when compared with untreated control group (Figure 1). The extract of POL-4 containing (150 and $300 \mathrm{mg} / \mathrm{kg}$ bw, orally) produced a significant ( $\mathrm{p}<0.05-0.01$ ) decline in glucose levels at 30 to 120 min intervals, with maximum effect at higher tested dose. Glibenclamide, an oral antidiabetic drug, administered at a dose of 6 $\mathrm{mg} / \mathrm{kg}$ bw, also, showed marked ( $\mathrm{p}<0.001$ ) decrease at 30 to $120 \mathrm{~min}$ intervals when compared with glucose only administered animals at respective time intervals.

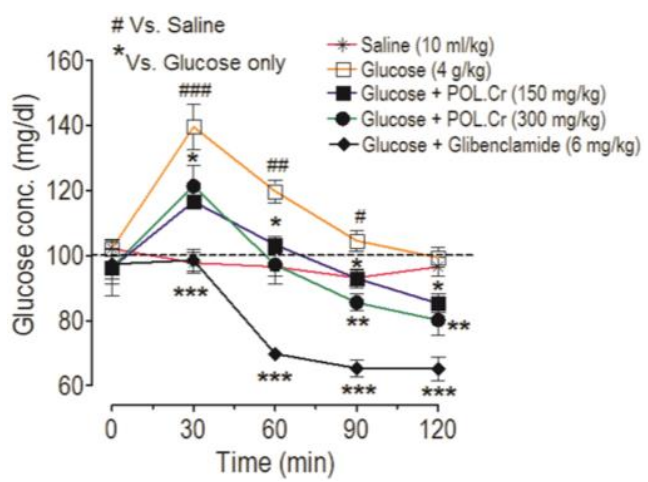

Figure 1.

Effect of POL-4 treatment on the oral glucose tolerance test (OGTT) in rats

Data is displayed as means \pm SEM. ns, non-significant, $\# p<0.05$, \#\# $<0.01$ and \#\#\# $<0.001$ show a comparison of glucose-induced hyperglycaemic control with normal saline (Student's $t$-test), while $* \mathrm{p}<0.05$, **p $<0.01$ and $* * * \mathrm{p}<0.001$ show a comparison of glucose-fed hyperglycaemic animals with animals of treatment groups (One way analysis of variance tailed by Dunnett's test). POL4.Cr: the aqueous-methanolic extract of polyherbal formulation

Effect of POL-4 treatment on physiological parameters in alloxan-challenged diabetic rats

When alloxan was administration to rats, it caused significant alterations in weight of the animals, systolic blood pressure (SBP), heart rate (HR), water and feed intake compared to data of animals fed normal diet (Table II). The POL-4 at 3 and 6\% mixed in the normal diet produced significant $(\mathrm{p}<0.01)$ improvement in water/feed intake, body weight, SBP and HR with greater improvement at higher tested dose. A noticeable $(\mathrm{p}<0.05)$ increase in body weight was also observed 
in the POL-4 treated animals compared to diabetic control animals (Table II).

On the other hand, glibenclamide $(6 \mathrm{mg} / \mathrm{kg}$ bw) administration to the animals through oral route showed a normalized trend in water intake, food intake and slightly increasing trend in body weight was observed when compared to diabetic control animals as seen in Table II.

Table II

Effect of POL-4 administration on body weight, water and food intake, systolic blood pressure and heart rate in

alloxan-induced diabetic rats

\begin{tabular}{|c|c|c|c|c|c|}
\hline Parameters & $\begin{array}{l}\text { Normal diet } \\
\text { (ND) treated }\end{array}$ & $\begin{array}{c}\text { Diabetic control rats } \\
\text { (Di) }\end{array}$ & $\begin{array}{c}\text { Diabetic + GB } \\
(6 \mathrm{mg} / \mathrm{kg} \mathrm{bw})\end{array}$ & $\begin{array}{c}\mathrm{Di}+\text { POL-4 } \\
(3 \%) \\
\end{array}$ & $\begin{array}{c}\text { Di + POL-4 } \\
(6 \%)\end{array}$ \\
\hline Body weight (g/gp/week) & $220 \pm 8.2$ & $162 \pm 7.5^{\# \# \#}$ & $190 \pm 4.6^{* * *}$ & $200 \pm 6.4 * * *$ & $210 \pm 5.6^{* * *}$ \\
\hline Food intake (g/gp/day) & $140 \pm 3.0$ & $130 \pm 2.6^{\mathrm{ns}}$ & $136 \pm 3.4^{\mathrm{ns}}$ & $133 \pm 5.0^{\mathrm{ns}}$ & $139 \pm 8.1^{\mathrm{ns}}$ \\
\hline Water intake (mL/gp/day) & $125 \pm 2.0$ & $150 \pm 5.3^{\# \#}$ & $112 \pm 6.5 * * *$ & $120 \pm 4.7 * *$ & $128 \pm 3.7 * *$ \\
\hline Systolic Blood Pressure (mmHg) & $118 \pm 4.5$ & $151 \pm 2.6^{\# \# \#}$ & $147 \pm 3.5^{\mathrm{ns}}$ & $140 \pm 2.8^{* *}$ & $133 \pm 6.4 * * *$ \\
\hline Heart rate (beats/min) & $322 \pm 3.5$ & $358 \pm 5.3^{\# \# \#}$ & $346 \pm 7.6^{\mathrm{ns}}$ & $339 \pm 6.2 * *$ & $328 \pm 5.9^{* * *}$ \\
\hline
\end{tabular}

$\# \# / *$ p < 0.01; \#\#\#/***p < 0.001; ns = non-significant; \# - show a comparison of diabetic control and normal saline (Student- $t$-test); $*$ - show a comparison of all treatment groups with Di (One way analysis of variance tailed by Dunnett's test); POL-4 = polyherbal formulation; $\mathrm{ND}=$ normal diet; diabetic control (Di); GB = glibenclamide; gp = group .

\section{Effect of POL-4 treatment on blood glucose and lipid} parameters in alloxan-fed rats

Administration of alloxan, in all animals except the animals of group one (to whom it was administered only the normal diet), induced hyperglycaemia and hyperlipidaemia as detailed in Table III. POL-4 administration (3\% and 6\%) mixed in normal feed caused significant reduction in the fasting blood glucose
(FBG) and serum total cholesterol (TC), low density lipoprotein cholesterol (LDL-C) and triglycerides (TG), while a mild increase was observed in high density lipoprotein cholesterol (HDL-C) compared to only alloxan administered diabetic rats. Similarly, administration of glibenclamide decreased significantly the blood glucose levels and lipid parameters compared to diabetic control group (Table III).

Effect of POL-4 administration on serum blood glucose and lipid profile in alloxan-induced-diabetic rats

\begin{tabular}{|l|c|c|c|c|c|}
\hline $\begin{array}{c}\text { Parameters } \\
(\mathbf{m g} / \mathbf{d l})\end{array}$ & $\begin{array}{c}\text { Normal Diet (ND) } \\
\text { treated }\end{array}$ & $\begin{array}{c}\text { Diabetic control rats } \\
(\mathbf{D i})\end{array}$ & $\begin{array}{c}\text { Diabetic + GB } \\
(\mathbf{6} \mathbf{~ m g} / \mathbf{k g} \text { bw) }\end{array}$ & $\begin{array}{c}\text { Di + POL-4 } \\
\mathbf{( 3 \% )}\end{array}$ & $\begin{array}{c}\text { Di + POL-4 } \\
(\mathbf{6 \%})\end{array}$ \\
\hline Glucose & $86.47 \pm 5.6$ & $276.4 \pm 15.2^{\# \# \#}$ & $98.4 \pm 7.30^{* * *}$ & $106.8 \pm 7.8^{* * *}$ & $94.5 \pm 6.9^{* * *}$ \\
\hline TC & $92.43 \pm 5.3$ & $143.6 \pm 3.7^{\# \# \#}$ & $99.5 \pm 8.1^{* *}$ & $102.8 \pm 3.20^{* *}$ & $96.83 \pm 5.3^{* * *}$ \\
\hline HDL-C & $34.58 \pm 2.9$ & $20.1 \pm 3.6^{\# \#}$ & $30.77 \pm 1.02^{*}$ & $30.5 \pm 2.3^{*}$ & $35.71 \pm 2.66^{* *}$ \\
\hline LDL-C & $57.50 \pm 3.4$ & $190.11 \pm 4.7^{\# \#}$ & $59.17 \pm 6.5^{*}$ & $62.4 \pm 3.6^{* *}$ & $58.2 \pm 3.14^{* * *}$ \\
\hline TG & $82.33 \pm 4.7$ & $179.85 \pm 6.7^{\# \# \#}$ & $94.0 \pm 4.4^{*}$ & $98.51 \pm 4.3^{*}$ & $87.62 \pm 3.1^{* * *}$ \\
\hline
\end{tabular}

$* \mathrm{p}<0.05 ; \# \# / * * \mathrm{p}<0.01 ; \# \# \# / * * * \mathrm{p}<0.001, \mathrm{~ns}=$ non-significant; \# - show a comparison of diabetic control with normal saline (Student- $t$ test), * show a comparison of all treatment groups with Diabetic control group (One way analysis of variance tailed by Dunnett's test). POL-4 = poly herbal formulation; ND = normal diet; $\mathrm{Di}=$ diabetic control; $\mathrm{TC}=$ total cholesterol; HDL-C = high density lipoproteincholesterol; LDL-C = low density lipoprotein-cholesterol; TG = triglycerides; $\mathrm{GB}$ = glibenclamide.

\section{Effect of POL-4 treatment on endothelial dysfunction} in alloxan-administered rats

The animals in diabetic control group showed endothelial dysfunction which was evident in the development of endothelial resistance to the acetylcholine mediated inhibitory responses in the aortic rings of alloxan administered rats as seen in Figure 2. POL-4 administration at $3 \%$ and $6 \%$ in normal feed to alloxaninduced diabetic rats caused significant improvement in the endothelial dysfunction by enhancing acetylcholine (ACh)-induced relaxation to $55.24 \pm 4.66$ and $47.30 \pm 3.4 v s .22 .91 \pm 3.53 \%,(n=4-6)$, respectively, at highest tested concentrations of $\mathrm{ACh}$. The comparisons of concentration response curves of $\mathrm{ACh}$ in the aortae of various groups have been shown in Figure 2.

Effect of POL-4 administration on histomorphometric characteristics of pancreatic tissues in alloxanadministered rats

Haematoxylin/eosin (H/E) stained tissue sections of pancreas in alloxan-induced model, microscopic examination (for islet number using photographic digital camera, while for islet diameter measurement, calibrated micrometre was used) of alloxan treated group showed shrinkage of islets of Langerhans, beta cell degranulation, decreased numbers and size of islets of Langerhans compared to normal rats (having normal islet numbers, islet diameters, acinar cells, vacuolation and vascular supply) as seen in Figure 3. However, treatment with POL-4 (6\%) and GB (6 $\mathrm{mg} / \mathrm{kg} \mathrm{bw}$ ) showed revival and improvement in the numbers of islets of Langerhans and beta cells compared to only alloxan challenged animals as shown in Figure 3. When assessed for the effect on the number of islets of Langerhans, it revealed a significant reduction in POL-4 treatment group with respective value of $9.29 \pm 2.58, \mathrm{n}=6$ ( $\mathrm{p}<0.05 \mathrm{vs}$. only alloxan treated animals), as shown in Figure 4A. Similarly, mean values of islet diameter of all groups were measured. POL-4 administration showed a marked increase in islet diameter with respective mean value 
of $122 \pm 3.53 \mu \mathrm{m}, \mathrm{n}=5$ ( $\mathrm{p}<0.05 v s$. only alloxan treated animals) as seen in Figure 4B.

Acute toxicity assay

Oral incubation of POL-4 and its ingredients at 1, 3 and $5 \mathrm{~g} / \mathrm{kg}$ bw in mice was devoid of any damage to vital organs, lethality or behavioural upsets such as writhing, palpitation or hyperventilation, lethargy, impaired motor actions mice within 48 hrs. POL-4 and its ingredients were found safe up to test dose of $5 \mathrm{~g} / \mathrm{kg}$.

Diabetes a commonly prevailing endocrine disorder labelled with sustained hyperglycaemia develops due to defect in insulin secretion and/or in its action. Increased hepatic gluconeogenesis and/or insulin resistance due to its less peripheral utilization are known to promote progression of diabetes. It is a major risk factor for cardiovascular disorders (CVDs), a common cause of mortality and morbidity among diabetic patients. Diabetes is associated with multiple complications like hyperlipidaemia, retinopathy, nephropathy, neuropathy, coronary artery and cerebrovascular diseases, thus posing a major health burden in societies across the globe [25].
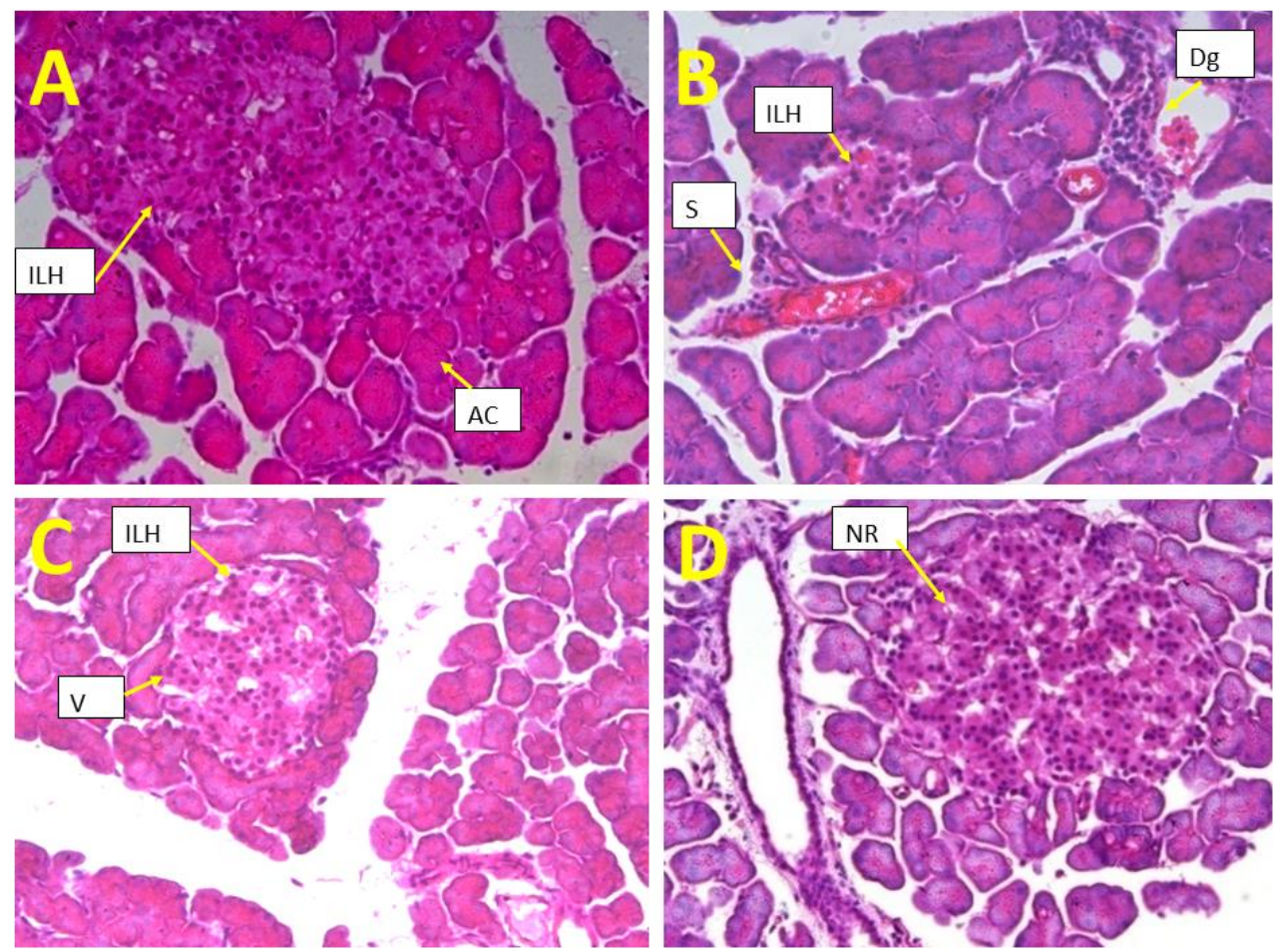

Figure 3.

Effect of POL-4 (6\%) administration on haematoxylin/eosin (H/E) stained pancreatic tissues observed at 400X showed the clusters of beta cells on central, while alpha cells in periphery

Arrows show islets of Langerhans (ILE), shrinkage (s), acinar cells (Ac), normal revived/restored (NR) beta cells, degranulation $(\mathrm{Dg})$ and vacuolation $(\mathrm{V})$

(A) Pancreatic tissues of animals on normal diet (B) Pancreatic tissues of alloxan- induced diabetic animals (C) Pancreatic tissues of alloxan- fed + glibenclamide $(6 \mathrm{mg} / \mathrm{kg})$ treated animals (D) Pancreatic tissues of alloxanfed + POL4 (6\%) administered rats 
A

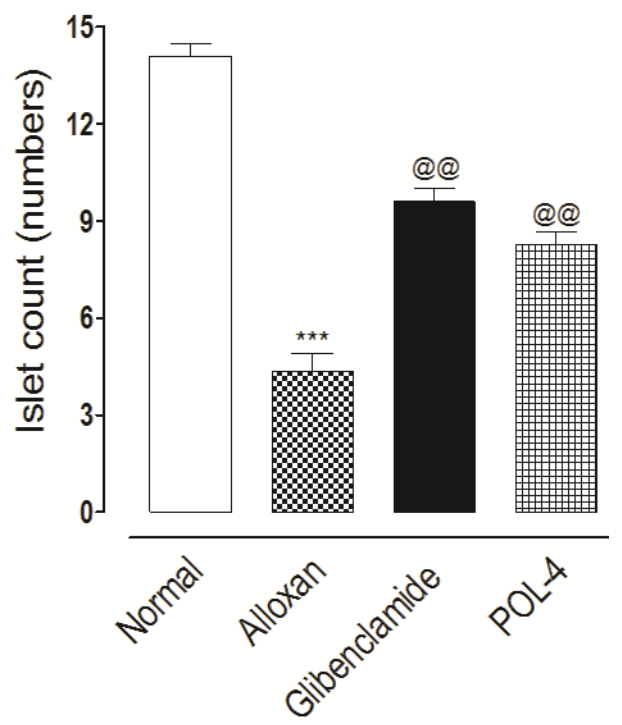

B

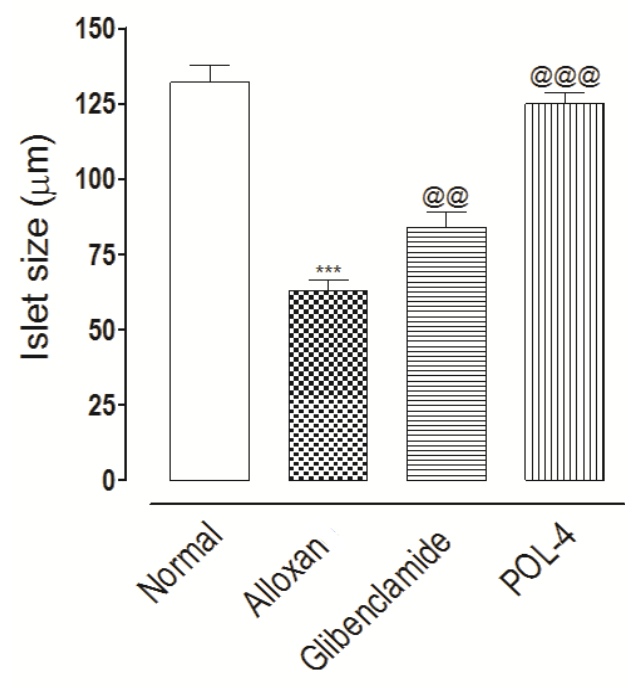

Figure 4.

Effect of POL-4 (6\%) intervention on (A) size $(\mu \mathrm{m})$ and $(B)$ number $\left(\mathrm{N} / 10 \mathrm{~mm}^{2}\right)$ of islets of Langerhans in alloxan-induced diabetic rats

Data show the means \pm S.E.M of 5 to 6 tissues from different animals; $* * * p<0.001$ show a comparison of alloxan administered rats with normal rats (Student's-t-test), while ${ }^{@} \mathrm{p} p<0.01$ and ${ }^{@ @ @ ~} \mathrm{p}<0.001$ show a comparison of treatments with only alloxan-fed animals (One way analysis of variance tailed by Dunnett's test). POL-4 = polyherbal formulation- 4

To address this multifactorial endocrine dysfunction, among multiple treatment modalities, the use of natural products has gained popularity for its therapeutic success and wide acceptance in different cultures. It has been widely attested that folk or ethno-medical information on medicinal herbs show the presence of biological constituent(s) which represent 'leads' that could shortcut the discovery of modern medicines. It has also been estimated that $>80 \%$ of people, equally in developed and emerging countries depend on traditional medicine to meet health care needs. Owing to lack of fully developed health care systems in developing countries, people with chronic diseases including diabetes, are among the worst victims [26]. In majority of traditional systems, diabetes is better managed by the herb combinations (poly herbal formulation) instead of prescribing a single herb, perhaps because of synergistic effectiveness and relatively lesser adverse effects [27].

Based on the folk use of POL-4 by traditional practitioners to treat diabetes in district Badin, Sindh, Pakistan, this study has been designed to provide an evidence to the medicinal use of POL-4 in diabetes and associated dysfunctions such as hyperlipidaemia, endothelial dysfunction and hypertension. Its antihyperglycaemic effects were observed through oral glucose tolerance test (OGTT) in rats, where the aqueous-methanolic extract of POL-4 (150 and $300 \mathrm{mg} / \mathrm{kg}$ bw) displayed prominent attenuation in the blood glucose levels similar to the effect of glibenclamide, a standard hypoglycaemic agent.
Administration of alloxan is well known in experimental animals to develop hyperglycaemia, hyperlipidaemia, endothelial dysfunction and hypertension. It is also known to charge histopathological changes in pancreatic tissues [28]. Alloxan is analogous to glucose which enters via glucose transporter-2 (GLUT 2 ) and accumulates in beta cells of pancreas. It has been used as diabetogenic agent to induce experimental diabetic animal models for the evaluation of synthetic and natural compounds. In addition, alloxan is converted into more toxic compound dialuric acid which further generates toxic free radicals like hydrogen peroxide, superoxide radicals and iron-hydroxyl radicals, which are responsible for beta cells necrosis and also lower the antioxidant defence mechanism that results in development of diabetes [29].

Administration of POL-4 powder (3\% and 6\% mixed in diet) to alloxan-fed diabetic rats, showed significant protection against raised blood pressure, heart rate, serum glucose and lipid parameters except high density lipoprotein cholesterol, which was slightly increased. The polyherbal intervention has also improved endothelial dysfunction and histomorphological alteration in pancreatic tissues. These results are similar to Jackson and Bressler [30] who observed that sulfonylureas have an effect not only on insulin release but also a positive impact on pancreatic tissue architecture. These findings on the part of POL-4 may add possible mechanism(s) to its therapeutic potential in diabetes. Moreover, insulin is well known to regulate lipid metabolism as well by inhibiting lipolysis through hormone-sensitive lipases in adipose tissues [31]. 
Superoxide and hydrogen peroxide is enhanced in diabetes through oxidation of glucose, glycation (nonenzymatic) of proteins and oxidative degradation of glycated proteins molecules. Imbalance between enhanced production of free radicals and a resultant decline in the antioxidant defensive mechanisms leads to cellular and enzymatic deterioration, while sustained increased lipid peroxidation mediates onset of insulin resistance and/or diabetes. These pathways of oxidative stress equally contribute in establishment of diabetes and related complications [32].

The observed antihyperglycaemic, antihyperlipidaemic, endothelial modulating and antihypertensive properties of POL-4 might be mediated by the known presence of antioxidant constituents of N. sativa, G. sylvestre, $T$. foenum graecum and $C$. intybus which have also shown their effectiveness in diabetes when studied using different models either as individual herb or in combination with other herbs [13, 15, 33-38]. Similarly, hydroxyisoleucine, the chemical constituents of $T$. foenum graecum is known to block inflammatory pathways and reduces symptoms of underlying disease [39]. This study may attest the selected combination of constituents of POL-4 has promising protective effects against diabetes; hence this formulation may further be subjected for chemical standardization and clinical trials to optimize its clinical efficacy in diabetes.

\section{Conclusions}

This study shows that polyherbal formulation (POL-4) possesses antihyperglycaemic, antihyperlipidaemic, endothelial modulating and antihypertensive properties possibly owned because of abundant presence of antioxidant constituents in the ingredients of POL4 , and or its inhibitory potential either on intestinal lipid absorption or lipid molecule synthesis. Thus, this study provides experimental evidence to the folk medicinal utility of POL-4 in diabetes and associated disorders.

\section{Acknowledgement}

The study was carried out during elective rotation of Mr. Abdul Malik, research volunteer, working with Dr. Malik Hassan Mehmood at Department of Biological and Biomedical Sciences. We would like to thank Dr. Nauman Aziz for his continuous guidance and providing us test materials.

\section{Conflict of interest}

The authors declare no conflict of interest.

\section{References}

1. World Health Organization, Diabetes fact Sheet, www.who.int/mediacentre/factsheets/fs312/en/, 2015.

2. Fowler MJ, Microvascular and macrovascular complications of diabetes. Clin Diabetes, 2008; 26(2): 77-82.
3. International Diabetes Federation: Diabetes atlas $6^{\text {th }}$ edition posters update 2014. Brussels, Belgium, 2014.

4. Khuwaja AK, Fatmi Z, Soomro WB, Khuwaja NK, Risk factors for cardiovascular disease in school children - a pilot study. J Pak Med Assoc., 2003; 53(9): 396-370.

5. American Diabetes Association, Economic costs of diabetes in the US in 2012. Diabetes Care, 2013; 36(4): 1033-1046.

6. Phillips PJ, Twigg SM, Oral hypoglycaemics: a review of the evidence. Aust Fam Physician, 2010; 39(9): 651-653.

7. Ekor M, The growing use of herbal medicines: issues relating to adverse reactions and challenges in monitoring safety. Front Pharm., 2014; 4: Art. 177: 1-10.

8. Mustafa SB, Mehmood Z, Akhter N, Kauser A, Hussain I, Rashid A, Akram M, Tahir IM, Munir N, Riaz M, Niazi SG, Medicinal plants and management of Diabetes Mellitus: A review. Pak J Pharm Sci., 2016; 29(5): 1885-1891.

9. Saravanan R, Pari L, Antihyperlipidemic and antiperoxidative effect of Diasulin, a polyherbal formulation in alloxan induced hyperglycemic rats. BMC Compl Altern Med., 2005; 5(1): 14: 1-8.

10. Pari L, Saravanan G, Antidiabetic effect of Cogent $\mathrm{db}$, a herbal drug in alloxan-induced diabetes mellitus. Compl Biochem Physiol Part C: Toxicol Pharmacol., 2002; 131(1): 19-25.

11. Malik A, Mehmood MH, Akhtar MS, Gilani A, Studies on antihyperlipidemic and endothelium modulatory activities of polyherbal formulation (POL4) and its ingredients in high fat diet-fed rats. Pak J Pharm Sci., 2017. 30(S1): 295-301.

12. Malik A, Mehmood MH, Channa H, Akhtar MS, Gilani $\mathrm{AH}$, Pharmacological basis for the medicinal use of polyherbal formulation and its ingredients in cardiovascular disorders using rodents. BMC Compl Altern Med., 2017; 17(1): 142: 1-12.

13. El Rabey HA, Al-Seeni MN, Bakhashwain AS, The antidiabetic activity of Nigella sativa and propolis on streptozotocin-induced diabetes and diabetic nephropathy in male rats. Evid Based Complement Altern Med., 2017; 2017: Art. 5439645: 1-15.

14. Street RA, Sidana J, Prinsloo G, Cichorium intybus: Traditional uses, phytochemistry, pharmacology, and toxicology. Evid Based Compl Altern Med., 2013; 2013: Art. 579319: 1-13.

15. Badale A, Pallag A, Kozma M, Hegedus C, Kovacs D, Gulyas H, Zdrinca M, Magyar I, Marc F, Nemeth S, Kiss R, Fenugreek seed and its active agent Diosgenin treatment effects on different Metabolic parameters in Rats. Farmacia, 2019; 67(1): 92-98.

16. Tiwari P, Mishra BN, Sangwan NS, Phytochemical and pharmacological properties of Gymnema sylvestre: an important medicinal plant. BioMed Res Int., 2014; 2014: Art: 830285: 1-18.

17. Williamson EM, Okpako DT, Evans FJ, Selection, preparation and pharmacological evaluation of plant material, vol. 1, John Wiley \& Sons., 1996; 15-23.

18. Evans WC, Trease and Evans Pharmacognosy, International Edition E-Book, 2009, Elsevier Health Sciences.

19. National Research Council: Guide for the Care and Use of Laboratory Animals Washington: 1996, National Academy Press. 
20. Szkudelski $T$, The mechanism of alloxan and streptozotocin action in B cells of the rat pancreas. Physiol Res., 2001; 50(6): 537-546.

21. Aziz N, Mehmood MH, Gilani AH, Studies on two polyherbal formulations (ZPTO and ZTO) for comparison of their antidyslipidemic, antihypertensive and endothelial modulating activities. BMC Complement Altern Med., 2013; 13(1): 371: 1-9.

22. Amin F, Gilani AH, Mehmood MH, Siddiqui BS, Khatoon N, Coadministration of Black seeds and Turmeric shows enhanced efficacy in preventing metabolic syndrome in fructose-fed rats. J Cardiovac Pharmacol., 2015; 65(2): 176-183.

23. Adeyemi DO, Komolafe OA, Adewole OS, Obuotor EM, Abiodun AA, Adenowo TK, Histomorphological and morphometric studies of the pancreatic islet cells of diabetic rats treated with extracts of Annona muricata. Folia Morphol., 2010; 69(2): 92-100.

24. Gilani AH, Khan AU, Ghayur MN, Ali SF, Herzig JW, Antispasmodic effects of Rooibos tea (Aspalathus linearis) is mediated predominantly through $\mathrm{K}+-$ channel activation. Basic Clin Pharmacol Toxicol., 2006; 99(5): 365-373.

25. World Health Organization. Definition, diagnosis and classification of diabetes mellitus and its complications: report of a WHO consultation. Part 1, Diagnosis and classification of diabetes mellitus. Geneva: WHO, 1999.

26. Orasanu G, Plutzky J, The pathologic continuum of diabetic vascular disease. J Am Coll Cardiol., 2009; 53(S5): S35-42.

27. Aslam MS, Ahmad MS, Mamat AS, Ahmad MZ, Salam F, An update review on polyherbal formulation: A global perspective. Sys Rev Pharm., 2016; 7(1): 35-41.

28. Chatzigeorgiou A, Halapas A, Kalafatakis K, Kamper $\mathrm{E}$, The use of animal models in the study of diabetes mellitus. In Vivo, 2009; 23(2): 245-258.

29. Lenzen $S$, The mechanisms of alloxan- and streptozotocininduced diabetes. Diabetologia, 2008; 51(2): 216-226.
30. Jackson JE, Bressler R, Clinical pharmacology of sulphonylurea hypoglycaemic agents: part 1. Drugs, 1981; 22(3): 211-245.

31. Hosseini A, Shafiee-Nick R, Ghorbani A, Pancreatic beta cell protection/regeneration with phytotherapy. Brazil J Pharma. Sci., 2015; 51(1): 1-6.

32. Maritim AC, Sanders RA, Watkins $3^{\text {rd }}$ JB, Diabetes, oxidative stress, and antioxidants: a review. $J$ Biochem Mol Toxicol., 2003; 17(1): 24-38.

33. Al-Waili N, Al-Waili H, Al-Waili T, Salom K, Natural antioxidants in the treatment and prevention of diabetic nephropathy; a potential approach that warrants clinical trials. Redox Report, 2017; 22(3): 99-118.

34. Ahamad R, Mujeeb M, Anwar F, Ahmad A, Pharmacological and molecular activity of methanolic extract of Cichorium intybus Linn seeds. Euro J Exp Biol., 2015. 5(7): 26-35.

35. Kang MH, Lee MS, Choi MK, Min KS, Shibamoto T, Hypoglycemic activity of Gymnema sylvestre extracts on oxidative stress and antioxidant status in diabetic rats. J Agri Food Chem., 2012; 60(10): 2517-2524.

36. Poongunran J, Perera HK, Fernando WI, Jayasinghe L, Sivakanesan R, alpha-Glucosidase and alphaAmylase Inhibitory Activities of Nine Sri Lankan Antidiabetic Plants. Br J Pharm Res., 2015; 7(5): 365-374.

37. Duraiswamy A, Shanmugasundaram D, Sasikumar CS, Cherian SM, Cherian KM, Development of an antidiabetic formulation (ADJ6) and its inhibitory activity against $\alpha$-amylase and $\alpha$-glucosidase. $J$ Trad Compl Med., 2016; 6(3): 204-208.

38. Srinivasan K, Cumin (Cuminum cyminum) and black cumin (Nigella sativa) seeds: traditional uses, chemical constituents, and nutraceutical effects. Food Quality Safety, 2018; 2(1): 1-6.

39. El-Kordy EA, Alshahrani AM, Effect of genistein, a natural soy isoflavone, on pancreatic $\beta$-Cells of streptozotocin-induced diabetic rats: histological and immunohistochemical study. J Microscopy Ultrastruct., 2015; 3(3): 108-119. 